\title{
Sulfcarbamide, A Blossom-thinning Agent for Apples
}

\author{
Max W. Williams ${ }^{1}$
}

Additional index words. apples, fruit set, blossom injury, fruit quality, chemical thinner, biennial bearing

Summary. In fruit-growing areas where pollination and fruit set conditions are optimum, biennial bearing is a regular occurrence unless steps are taken to reduce fruit set in the heavy bloom year. In the past, a two- or three-spray thinning program was used in the state of Washington on difficult cultivars, consisting of Elgetol at bloom time, followed by a petal fall spray of Amide-thin, followed by a later postbloom spray of NAA or Sevin. In 1989, Elgetol was removed from the market by the manufacturer because of the high cost of re-registration. In 1990, a search for an Elgetol replacement was initiated. Elgetol was a contact spray that damaged flower parts and prevented fertilization of the ovule. Thus, it was logical to look for other products that had a similar mode of action. Sulfcarbamide (monocarbamide dihydrogen sulfate) (D-88) (Wilthin), a foliage desiccant used on potatoes, onions, and alfalfa, and tested as a dilute full-volume spray on apple blossoms, was found to be an effective blossom thinner. Chemical rates of $0.25 \%$ to $0.5 \%(v / v)$ applied at $80 \%$ of bloom open reduced fruit set by $25 \%$ to $50 \%$ compared to controls.

B lossom-thinning of apple (Malus domestica Borkh.) has been an important part of fruit-thinning programs in Washington and other western states to help offset biennial bearing (Williams and Edgerton, 1981). Russel and Pickering (1919) showed convincingly that the alternate-bearing habit of apples could be controlled if thinning was practiced at time of bloom. In spite of this early knowledge and the need by the apple industry, the only chemical blossom 
thinner developed and used commercially was Elgetol, a dinitro-orthocresol compound. Elgetol was used extensively in western U.S. apple production areas from 1950 through the 1980s.

The first trials with D-88 (sulfcarbamide) on apples were in Australia in 1990. In 1991, 0.25-ha plots in Washington were treated with D-88. To date, testing has been conducted over four seasons-two in Australia and two in Washington. In all trials, fullbearing apple trees were selected for uniformity of growth and rated for amount of bloom. Only trees with $85 \%$ or more of the growing points with flowers were used for data collection. Single-tree replicates in uniform rows with buffer trees between rows and treatments were used; three uniformly blossoming limbs per tree were tagged, and blossom clusters were counted. Following treatment, and after the first wave of drop was over, the number of fruits on each of the count limbs was counted and recorded. Results are expressed as number of fruit per 100 blossom clusters. In the initial trials in Australia, three trees per treatment were used and, in the large 0.25-ha plots, 10 trees were used per treatment with two counted limbs per tree. Treatments in the Australia trials were applied with high-pressure handguns. The larger plots in Washington were sprayed with commercial air-blast sprayers. Dilute, full-volume sprays were used in all trials and the foliage was sprayed to runoff. The WallerDuncan K-ratio $t$ test was used to test for differences among treatments and controls (SAS Institute, 1987).

Sulfcarbamide was $79 \%$ a.i. formulated product. The concentrations tested experimentally were from $0.25 \%$ to $1.0 \%(\mathrm{v} / \mathrm{v})$. The commercial-size plots were treated with concentrations of $0.25 \%, 0.375 \%$, and $0.5 \%(\mathrm{v} / \mathrm{v})$. In the 1991 Washington trials, two applications of $0.25 \%$ at $70 \%$ and $90 \%$ open blooms were compared with a single application. All other treatments were applied at $80 \%$ to $90 \%$ open bloom stage. Elgetol at $0.25 \%(\mathrm{v} / \mathrm{v})$ was included as a comparison with D-88.

The 1992 tests in Australia and Washington were conducted to determine the effect of temperature and previous sprays, such as mineral elements, on potential fruit injury. In Australia, sprays were applied in early morning, at midday, and in early

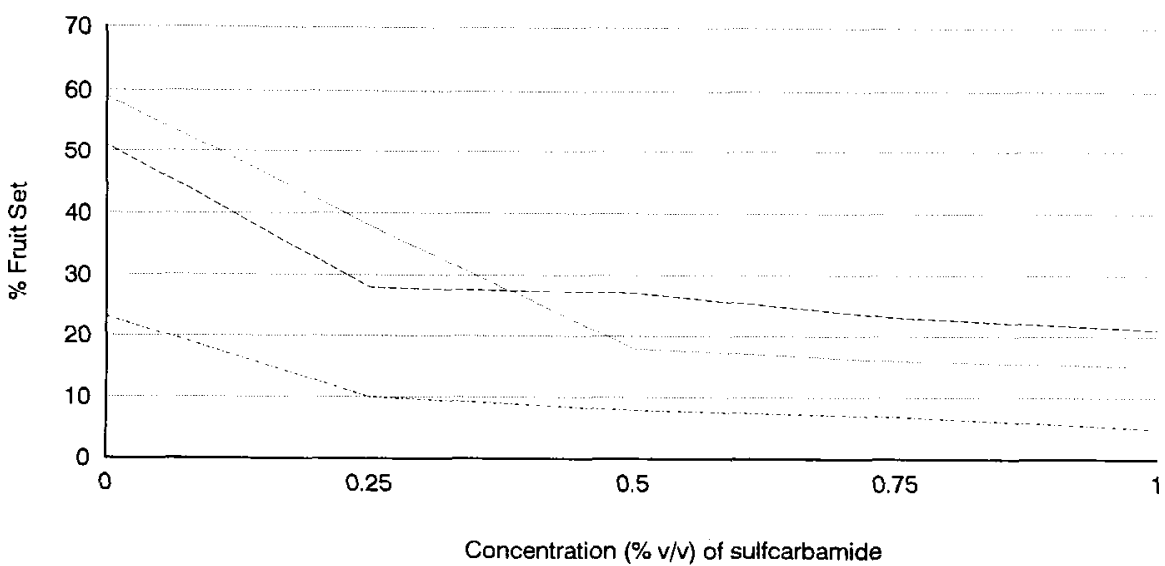

Fig. 1. Sulfcarbamide (D-88) fruit set, blossom-thinning trials, Orange, New South Wales, Australia, 1990. Dotted line = standard 'Delicious'; dashed line = 'Granny Smith'; dashed/dotted line $=$ 'Red Chief Delicious'. evening; the temperature spread was 10 to $15 \mathrm{C}$. In Washington, the mineral element sprays copper, boron, and zinc were applied 2 weeks before the D-88 treatments. Fruit injury ratings were made before harvest on 100 fruit/ tree and scored for severity from 1 to 5 ; ratings of 4 and 5 were commercially unacceptable, with a 5 rating having total marks of five or more per fruit.

Results of the initial 1990 Australia trials on efficacy of D-88 on two strains of 'Delicious' and 'Granny Smith' are shown in Fig. 1. Trial 1 was with 20-year-old standard 'Delicious',
Trial 2 was with 7-year-old 'Granny Smith', and Trial 3 was with 4-yearold grafts of 'Red Chief Delicious'. Fruit set reduction occurred on all cultivars and at all chemical concentrations.

Results from the 1991 trials with commercial-size plots in Washington are presented in Tables 1 and 2. In all trials, D-88 was as effective a thinner as Elgetol and was not affected by weather after drying. On all cultivars, the $0.375 \%(\mathrm{v} / \mathrm{v})$ rate of $\mathrm{D}-88$ was as active as the $0.25 \%$ rate applied twice. The $0.5 \%$ rate caused over-thinning on
Table 1. Chemical thinning of 'Delicious' apples with sulfcarbamide (D-88), 1991.

\begin{tabular}{|c|c|c|c|c|}
\hline \multirow[b]{2}{*}{ Treatment $^{2}$} & \multicolumn{2}{|c|}{ Yakima, Wash. } & \multicolumn{2}{|c|}{ Wenatchee, Wash. } \\
\hline & $\begin{array}{l}\text { No. fruit/100 } \\
\text { blossom clusters }\end{array}$ & $\begin{array}{c}\text { Percent of } \\
\text { control }\end{array}$ & $\begin{array}{l}\text { No. fruit/100 } \\
\text { blossom clusters }\end{array}$ & $\begin{array}{c}\begin{array}{c}\text { Percent of } \\
\text { control }\end{array} \\
\end{array}$ \\
\hline Controls & 196 & $100 a^{r}$ & 122 & $100 \mathrm{a}$ \\
\hline Elgetol, $025 \%(\mathrm{v} / \mathrm{v})$ & 165 & $84 b c$ & 80 & $65 c$ \\
\hline D. $88,0.25 \%(v / v)$ & 177 & $90 \mathrm{ab}$ & 94 & $77 \mathrm{~b}$ \\
\hline $\mathrm{D}-88,0.25 \%(\mathrm{v} / \mathrm{v})$ twice & 146 & $74 \mathrm{c}$ & 78 & $64 c$ \\
\hline $\mathrm{D}-88,0.375 \%(\mathrm{v} / \mathrm{v})$ & 170 & $87 \mathrm{~b}$ & 72 & $59 c$ \\
\hline D- $88,0.5 \%(v / v)$ & 127 & $65 \mathrm{~d}$ & 44 & $36 \mathrm{~d}$ \\
\hline
\end{tabular}

sTreatments applied at 70\% to $90 \%$ open bloom.

${ }^{y}$ Treatments with a common letter are different by Waller-Duncan analysis, $K$-ratio $\mathrm{t}$ test, $\mathrm{P} \leq 0.05$.

Table 2. Chemical thinning of 'Fuji' and 'Gala' apples with sulfcarbamide (D-88) at Vantage, Wash., 1991.

\begin{tabular}{|c|c|c|c|c|}
\hline \multirow[b]{2}{*}{ Treatment $^{2}$} & \multicolumn{2}{|l|}{$\begin{array}{r}\text { Fuji } \\
\end{array}$} & \multicolumn{2}{|l|}{ Gala } \\
\hline & $\begin{array}{c}\text { No. fruit/100 } \\
\text { blossom clusters }\end{array}$ & $\begin{array}{c}\text { Percent of } \\
\text { control }\end{array}$ & $\begin{array}{c}\text { No. fruit/100 } \\
\text { blossom clusters }\end{array}$ & $\begin{array}{c}\text { Percent of } \\
\text { control }\end{array}$ \\
\hline Controls & 232 & $100 a^{y}$ & 237 & $100 \mathrm{a}$ \\
\hline Elgetol, $025 \%(\mathrm{v} / \mathrm{v})$ & 203 & $87 \mathrm{ab}$ & 189 & $79 \mathrm{~b}$ \\
\hline $\mathrm{D}-88,0.25 \%(\mathrm{v} / \mathrm{v})$ & 171 & $73 \mathrm{bc}$ & 170 & $71 b$ \\
\hline $\mathrm{D}-88,0.25 \%(\mathrm{v} / \mathrm{v})$ twice & 152 & $65 c$ & 140 & $59 \mathrm{c}$ \\
\hline $\mathrm{D}-88,0.375 \%(\mathrm{v} / \mathrm{v})$ & 150 & $64 c$ & 112 & $47 \mathrm{~cd}$ \\
\hline $\mathrm{D}-88,0.5 \%(\mathrm{v} / \mathrm{v})$ & 175 & $75 \mathrm{bc}$ & 105 & $44 \mathrm{~d}$ \\
\hline
\end{tabular}

${ }^{5}$ Treatments applied at $70 \%$ to $90 \%$ open bloom.

${ }^{y}$ Treatments with a common letter are different by Waller-Duncan analysis, $K$-ratio $\mathrm{t}$ test, $\mathrm{P} \leq 0.05$. 

der-thinned by Elgetol and all concentrations of D-88. Ideal blossom thinning in Washington is when treated trees have between $50 \%$ and $75 \%$ as much fruit as control trees.

Fruit from the 'Delicious' trial in and packed on a commercial line. The plot size was 0.25 ha/treatment. The yield for the $0.5 \%(\mathrm{v} / \mathrm{v})$ rate was slightly less than other treatments due to thinning, but the number of packed boxes of Washington Extra Fancy fruit and the number of packed boxes of size 100 through 72 were higher in both the $0.375 \%$ and $0.5 \%$ D-88 treatments (Table 3). The overall packout for the treated fruit was much better than for the control. Some of the treated fruit had minor fruit markings similar to insect stings, but injury did not affect the pa\&out. The larger amount of culls in the control was mainly because

In the 1991 tests in Australia, designed to determine the effect of temperature at time of spray application on fruit injury, there was no effect of temperatures between 18 and 30C. In all except one trial the damage was $<1 \%$. The one exception was on 'Gala' treated with a delayed dormant spray of Kocide before the D-88 application. Apparently, the D-88 reactivated the copper deposit on fruit and resulted in nearly $50 \%$ of fruit with a russet deformation type of injury. Results of 1992 trials on 'Delicious' in Washington designed to determine effect of delayed dormant sprays and
'Delicious' and 'Gala'. 'Fuji' was unYakima, Wash., were harvested, graded, of small fruit.

Table 4. Delicious' fruit damage from $D-88,0.375 \%(v / v)$ treatments, 1992.

\begin{tabular}{|c|c|c|c|c|c|c|}
\hline \multirow[b]{2}{*}{ Treatments } & \multirow{2}{*}{$\begin{array}{c}\text { Time applied } \\
\text { (percent bloom) }\end{array}$} & \multicolumn{5}{|c|}{ Avg, no. of fruit/severity category ${ }^{4}$} \\
\hline & & 1 & 2 & 3 & 4 & 5 \\
\hline Copper $+\mathrm{D}-88^{y}$ & 90 & 16 & 15 & 12 & 6 & 20 \\
\hline Boron + D-88 & 90 & 24 & 6 & 9 & 2 & 9 \\
\hline $\operatorname{Zinc}+\mathrm{D}-88^{y}$ & 90 & 17 & 3 & 9 & 1 & 7 \\
\hline D-88 late & 100 & 3 & 2 & 4 & 1 & 14 \\
\hline D-88 early & 80 & 13 & 4 & 5 & 2 & 1 \\
\hline D-88 + Regulaid & 85 & 8 & 3 & 4 & 0 & 1 \\
\hline Control & --- & 2 & 0 & 0 & 0 & 0 \\
\hline
\end{tabular}

${ }^{2}$ Number offruitinjured/1 00 king fruit. Injury rating: 1 + one mark/fruit; 5 =fipe or more marks/fruit. "Boron, copper, and zinc sprayed 2 weeks before D-88. early compared to late application of D-88 on fruit injury are presented in Table 4. In these trials, Kocide sprays applied 2 weeks before D-88 caused severe fruit injury. Late applications of D-88 after $100 \%$ of blossoms were open and king bloom fruit were formed resulted in more fruit injury than earlier sprays when only $80 \%$ of blossoms were open. Boron and zinc sprays followed by D-88 slightly increased fruit damage.

In conclusion, D-88 was an effective blossom-thinning agent, as consistent as Elgetol, was not affected by weather conditions before and after application, and was nonresidual.

In $>90 \%$ of the experimental trials and commercial applications, fruit injury was not a problem. However, to avoid potential fruit damage, delayed dormant sprays of mineral elements should be applied before flower clusters begin to open.

Concentrations of $0.25 \%$ to $0.375 \%(\mathrm{v} / \mathrm{v})$ of $\mathrm{D}-88$ were effective on all apple cultivars tested except
Table 3. Packout summary of D-88-treated 'Delicious' trial at Yakima, Wash., 1991.

\begin{tabular}{lcccc}
\hline Yield and grade & Cks & 0.375\%(v/v) & $0.5 \%(\mathrm{v} / \mathrm{v})$ & Elgetol $0.25 \%(\mathrm{v} / \mathrm{v})$ \\
\hline Bins (25 box) & $33^{z}$ & 32 & 31 & 33 \\
& \multicolumn{4}{c}{ Packout data } \\
$W \times \mathrm{F}^{y}$ & 432 & 489 & 488 & 472 \\
Fancy & 61 & 51 & 57 & 51 \\
Bags $(5 \mathrm{~kg})$ & 161 & 111 & 99 & 134 \\
Culls $(\mathrm{kg})$ & 871 & 617 & 792 & 792 \\
Size $100-72^{y}$ & 329 & 396 & 394 & 370
\end{tabular}

zYield is from $0.2 .5 \mathrm{ha}$.

${ }^{y}$ Washington Extra Fancy and Fancy total number of packed boxes (18 kg).
'Fuji'. The degree of fruit reduction depends on the number of open blossoms and the number of flowers pollinated and fertilized before sprays are applied.

In 1992, the test plots and >200 acres of apples were treated in Washington and other western states. In 1993, sulfcarbamide was available as Wilthin for commercial sales for $15 \%$ of total apple acreage in Washington, Oregon, and Idaho.

\section{Acknowledgement}

I thank Dwayne Visser, Agriculture Research Technician, for his persistence in these trials. Thanks go to Greg Madafiglio, Keith Jones, and Steve Myers for help with the Australian trials. Sulfcarbamide was supplied by Union Oil Co. of Los Angeles. Names are necessary to report factually on available data; however, the USDA neither guarantees nor warrants the standard of the product, and the use of the name by USDA implies no approval of the product: to the exclusion of others that may also be suitable.

\section{Literature Cited}

Russel, H.A. and S. Pickering. 1919. Science and fruit growing. Macmillan, New York.

SAS Institute. 1987. SAS/STAT guide for personal computers. Version 6 ed. SAS Institute, Inc., Cary, N.C.

William, M.W. and L.J. Edgerton. 1981. Fruit thinning of apples and pears with chemicals. USDA Agr. Bul. 289. 